\title{
Bcl-2/Bcl-XL Inhibitor APG-1252
}

National Cancer Institute

\section{Source}

National Cancer Institute. BCl-2/BCl-XL Inhibitor APG-1252. NCI Thesaurus. Code C148488.

A Bcl-2 homology (BH)-3 mimetic and selective inhibitor of the anti-apoptotic proteins Bcell lymphoma 2 ( $\mathrm{Bcl}-2)$ and $\mathrm{Bcl}-\mathrm{XL}$, with potential pro-apoptotic and antineoplastic activities. Upon administration, Bcl-2/Bcl-XL inhibitor APG-1252 specifically binds to and inhibits the activity of the pro-survival proteins $\mathrm{BCl}-2$ and $\mathrm{BCl}-\mathrm{XL}$. This restores apoptotic processes and inhibits cell proliferation in $\mathrm{Bcl}-2 / \mathrm{Bcl}-\mathrm{XL}$-dependent tumor cells. $\mathrm{Bcl}-2$ and $\mathrm{Bcl}-\mathrm{XL}$, proteins belong ing to the $\mathrm{Bcl}-2$ family that are overexpressed in many cancers, play an important role in the negative regulation of apoptosis; tumor expression is associated with increased drug resistance and cancer cell survival. 